\title{
Benzyladenine as A Chemical Thinner for 'McIntosh' Apples. I. Fruit Thinning Effect1s and Associated Relationships with Photosynthesis, Assimilate Translocation, and Nonstructural Carbohydrates
}

\author{
Rongcai Yuan ${ }^{1}$ and Duane W. Greene ${ }^{2}$ \\ Department of Plant and Soil Sciences, University of Massachusetts, Amherst, MA 01003
}

AdDITIONAL INDEX WORDS. cytokinin, BA, fruit abscission, fruit quality, respiration, Malus sylvestris var. domestica

\begin{abstract}
BA was applied at 50 or $100 \mathrm{mg} \cdot \mathrm{L}^{-1}$ to 'More-Spur McIntosh'/Malling 7 (M.7) apple trees [Malus sylvestris (L.) Mill var.domestica (Borkh.) Mansf.] at the $10 \mathrm{~mm}$ stage of fruit development. BA thinned fruit and increased fruit size. There were two distinguishable peaks of fruit abscission during ' June drop'. BA accentuated the naturally occurring waves of fruit abscission, and enhanced translocation of ${ }^{14} \mathrm{C}$-sorbitol from leaves to fruit when applied directly to the fruit, but not when applied directly to the leaves. Net photosynthesis was decreased and dark respiration was increased when temperature following $\mathrm{BA}$ application was high $\left(30^{\circ} \mathrm{C}\right)$, whereas there was no effect when temperature was lower $\left(20^{\circ} \mathrm{C}\right)$. Total nonstructural carbohydrates, total soluble sugars, and starch in the leaves decreased dramatically over the 12- or 13-day observation period, regardless of BA treatment. These carbohydrate concentrations in the leaves were lowered further by BA application. Abscising fruit, based on specific reddening of the pedicel, had higher carbohydrate levels than persisting fruit, regardless of BA application. We conclude that BA thins fruit, at least in part, by increasing dark respiration and decreasing net photosynthesis. Chemical name used: $\mathrm{N}$-(phenylmethyl)-1H-purine-6-amine [benzyladenine (BA)].
\end{abstract}

Fruitlet thinning is one of the most important management practices a commercial grower is required to do to produce high quality apples (Malus sylvestris var. domestica). Thinning improves fruit size, color, and quality at harvest, and increases return bloom the following year, thereby reducing alternate bearing (Childers et al., 1995). Chemical thinning is superior to hand thinning because it is less expensive and it can be done earlier (Childers et al., 1995).

Since the initial suggestion by Mclaughlin and Greene (1984) that BA might be a good chemical thinner for apples, there have been a number of reports that have confirmed its effectiveness as a chemical thinner on many apple cultivars (Bound et al., 1991; Elfving and Cline, 1993; Greene et al., 1990; Wismer et al., 1995). Recently Accel (Abbott Laboratory, North Chicago, IL), an altered Promalin formation that contains $90 \% \mathrm{BA}$ and $10 \%$ gibberellins ${ }_{4+7}\left(\mathrm{GA}_{4+7}\right)$, was registered for use as a chemical thinner for apples. The mechanism whereby BA thins is unclear. Previous reports showed that BA at 50 to $100 \mathrm{mg} \cdot \mathrm{L}^{-1}$ is generally required to thin effectively (Bound et al., 1991; Greene and Autio, 1989; Greene et al., 1990), and the maximum thinning response occurs when BA is applied at the 10 to $14 \mathrm{~mm}$ stage of fruit development, which is frequently $\approx 14$ to $21 \mathrm{~d}$ after full bloom (Bound et al., 1991; Greene and Autio, 1989). BA, similar to another chemical thinner naphthaleneacetic acid (NAA) (Schneider, 1978), thins apples more effectively when applied to the leaves than to the fruit (Greene et al., 1992). Lack of significant thinning can not be attributed to lack of BA absorption by the fruit because considerably more BA enters the fruit than enters through either surface of the leaves (Greene et al., 1992). BA treatments that thinned also increased ethylene production in both

Received for publication 19 Apr. 1999. Accepted for publication 26 Oct. 1999 The cost of publishing this paper was defrayed in part by the payment of page charges. Under postal regulations, this paper therefore must be hereby marked advertisement solely to indicate this fact.

${ }^{1}$ Former graduate research assistant. Current address: University of Florida, Citrus Research and Education Center, 700 Experiment Station Road, Lake Alfred, FL 33850-2299.

${ }^{2}$ Professor. leaves and fruit $24 \mathrm{~h}$ after application, but the magnitude of increase was quite small and not considered large enough to be the primary cause for thinning (Greene et al., 1992).

Carbohydrates have been implicated in fruit set and fruit development. It has been suggested that the mechanism of fruit thinning by NAA is due to reduced energy available to developing fruit either by interference with photosynthesis (Stopar et al., 1997) or by the reduced translocation of metabolites, including photosynthates, from leaves to the fruit ( Schneider, 1975, 1978). Two days of artificial shade decreased photosynthesis, reduced the carbohydrates available to the fruitlets, and induced more apple abscission than NAA, ethephon (2-chloroethylphosphonic acid), or carbaryl (1-naphthalenyl methylcarbamate) + oil spray. Shading of whole trees for $3 \mathrm{~d}$ caused $98 \%$ fruit abscission (Byers et al., 1991). Fruit from artificially shaded trees or those from trees receiving the photosynthetic inhibitor terbacil (3-tert-butyl-5-chloro-6methyluracil) had lower total sugars and reducing sugars than those not treated (Polomski et al., 1988). However, Abruzzese et al. (1995) reported that abscised apples had higher levels of soluble reducing sugars and sucrose than persisting fruit. Also, abscising naval orange fruit [Citrus sinensis (L.) Osbeck] had higher reducing sugars and total sugars than persisting fruit (Ruiz and Guardiola, 1994).

The overall goal of this investigation was to determine the mode of action of BA as a chemical thinner on apples. To accomplish this, the specific objectives of this study were to 1) evaluate the effect of BA on the translocation of assimilate from leaves to young growing fruit; 2) measure net photosynthetic rates and mitochondrial respiration rates of apple leaves at different temperatures following BA application; and 3) determine theinfluence of BA on the nonstructural carbohydrate status in the leaves and fruits of apples and its relation to apple abscission.

\section{Materials and Methods}

All orchard experiments were conducted at the University of Massachusetts, Horticultural Research Center, Belchertown, Mass. 
${ }^{14}$ C-ASsimilate movement IN 1995 (EXPT. 1). Fruiting spurs of 'More-Spur McIntosh'/Malling 7 (M.7) apples were excised on 31 May 1995 when average fruit size was $10 \mathrm{~mm}$. They were placed in water and transported to the laboratory. Thirty uniform spurs with three leaves and a $10 \mathrm{~mm}$ diameter size fruit were selected, and placed in individual flasks with distilled water at room temperature $\left(\approx 27^{\circ} \mathrm{C}\right)$. A randomized complete block design with 10 replications was used. Leaves on one group of 10 spurs and fruit on anther group of 10 spurs were dipped into BA solution (ABG-3062, Abbott Laboratory, North Chicago, Ill.) at $100 \mathrm{mg} \cdot \mathrm{L}^{-1}$. The third group of 10 spurs were not treated and served as the control. After the BA solution dried, a circle $2 \mathrm{~cm}$ in diameter was outlined with dots of India ink on the abaxial surface of one leaf on each spur. Sixteen L ${ }^{14} \mathrm{C}$-sorbitol $\left(2.96 \times 10^{4} \mathrm{~Bq}\right)$ were applied within the marked area on the abaxial surface of the leaf using a microsyringe attached to a repeating dispenser (Model PB 600-1; Hamilton, Reno, Nev.). Twenty four hours after treatment, spurs were harvested and separated into fruit, stems, $2 \mathrm{~cm}$ marked portions of the treated leaves, the remaining treated leaves, and the other nontreated leaves. The treated leaf disks were each rinsed with $5 \mathrm{~mL}$ distilled water containing $0.1 \% \mathrm{X}-77$ surfactant and then $5 \mathrm{~mL}$ distilled water. The samples were sliced, dried at $70^{\circ} \mathrm{C}$ for $5 \mathrm{~d}$, and oxidized for $5 \mathrm{~min}$ in a biological material oxidizer (model OX-400; Harvey Instrument Corp., Hillside, N.J.). Evolved ${ }^{14} \mathrm{CO}_{2}$ was collected in an external trap containing $15 \mathrm{~mL}$ Harvey ${ }^{14} \mathrm{C}$ cocktail. Radioactivity was determined by a liquid scintillation counter (Model 3801; Beckman, Fullerton, Calif.). Counts were adjusted to account for quenching and for biological oxidizer efficiency.

${ }^{14}$ C-ASSimilate MOVEMENT IN 1996 (EXPT. 2). The effect of BA on the movement of assimilate from leaves to young growing fruit was similarly evaluated in 1996. Fruiting spurs with average fruit size diameter of $10 \mathrm{~mm}$ were harvested on 30 May and treated as above. At 24 and $48 \mathrm{~h}$ after application of $16 \mu \mathrm{L}^{14} \mathrm{C}$-sorbitol $\left(2.96 \times 10^{4} \mathrm{~Bq}\right)$ within the marked area on the abaxial surface of the leaf, spurs were harvested, separated into component parts, and analyzed for ${ }^{14} \mathrm{C}$ as described above.

NET PHOTOSYNTHESIS AND RESPIRATION IN 1996 (EXPT. 3). Twenty four 3-year-old young 'More-Spur McIntosh'/M.7 apple trees growing in 19-L containers outside the greenhouse at the University of Massachusetts were blocked based upon vigor into eight groups (replications) of three trees each. A randomized complete block design was used. One uniform fully expanded leaf (the fifth or sixth from the shoot apex) with good light exposure was tagged. One tree in each replication received a dilute spray of BA at 50 or $100 \mathrm{mg} \cdot \mathrm{L}^{-1}$. One tree in each replication was not sprayed and served as a control. Exchange rate of $\mathrm{CO}_{2}$ was measured using a portable photosynthesis system (LI-6200; LI-COR, Lincoln, Nebr.) equipped with a $250 \mathrm{~mL}$ leaf chamber (total system gas volume $=390 \mathrm{~mL}$ ). The rectangular area of the leaf enclosed in the closed leaf chamber was $13.6 \mathrm{~cm}^{2}$. Measurements were made at $0,1,6$, and $8 \mathrm{~d}$ after BA application. Leaf net photosynthesis $\left(\mathrm{P}_{\mathrm{n}}\right)$ at high temperature was measured between 9:30 AM and 12:30 PM on clear, sunny days. Environmental conditions during measurements were as follows: photosynthetic photon flux, 1800 to $2000 \mu \mathrm{mol} \cdot \mathrm{m}^{-2} \cdot \mathrm{s}^{-1}$; air temperature $30 \pm 2{ }^{\circ} \mathrm{C}$; leaf temperature, $29 \pm 2{ }^{\circ} \mathrm{C}$; ambient $\mathrm{CO}_{2}$ concentration, $330 \pm 10$ $\mu \mathrm{mol} \cdot \mathrm{mol}^{-1}$. The mitochondrial respiration of leaves at high (air temperature $30 \pm 2{ }^{\circ} \mathrm{C}$; leaf temperature, $29 \pm 2{ }^{\circ} \mathrm{C}$ ) and low temperature (air temperature, $20 \pm 0.5^{\circ} \mathrm{C}$; leaf temperature, $19.5 \pm$ $0.5^{\circ} \mathrm{C}$ ) were measured using black cloth to cover the leaf chamber and eliminate light. Complete blocks were measured to minimize environmental effects during any one measurement date.

Fruit thinNing, abscission, AND NONSTRUCTURAL CARbOHY-
DRATE STATUS IN 1995 (EXPT. 4). Twenty-four mature 'More-Spur McIntosh'/M.7 apple trees were selected and grouped based upon vigor and blossom cluster density into eight blocks of three trees each. A randomized complete block design was used. Two limbs on each tree, 12 to $15 \mathrm{~cm}$ in diameter, were tagged and all blossom clusters were counted before bloom. One tree in each block received a spray of BA (ABG-3062, Abbott Laboratory) at either 50 or 100 $\mathrm{mg} \cdot \mathrm{L}^{-1}$ on 1 June 1995 , at the $10 \mathrm{~mm}$ stage of fruit development. One tree in each block was not sprayed and served as a control. All fruit remaining on tagged limbs were counted at the end of the June drop period in July. Fruit weight was evaluated at commercial harvest.

Fifteen fruits and 20 spur leaves were collected from each tree at $0,5,8$, and $12 \mathrm{~d}$ after BA application, and were placed immediately in a container with dry ice and transported to the laboratory. All the samples were dried in a forced-air oven at $70^{\circ} \mathrm{C}$ for $5 \mathrm{~d}$, weighed, and ground in Wiley mill to pass a $40-$ mesh $(0.635-\mathrm{mm})$ screen and used for analysis of total soluble sugars and starch.

The method of Belding and Young (1987) was used to extract plant material for total soluble sugars. Total soluble sugars were determined by the colorimetric method of Flood and Priestley (1973). Starch was extracted and hydrolyzed with amyloglucosidase (Sigma, St. Louis, Mo.) (Dekker and Richards, 1971). The glucose concentration produced from the enzymic hydrolysis of starch was assayed according to Flood and Priestley (1973).

Fruit ThinNING, ABSCISSION, AND NONSTRUCTURAL CARbOHYDRATE STATUS IN 1996 (EXPT. 5). Effects of BA on fruit thinning, and nonstructural carbohydrate levels in leaves and fruits were examined similarly on a block of mature 'More-Spur McIntosh'/M.7 apple trees. Twenty-four trees were selected and grouped based upon vigor and blossom cluster density into eight blocks of three trees each. BA (ABG-3062, Abbott Laboratory, North Chicago, IL) was applied on 30 May 1996, at the 10-mm stage of fruit development. Fruit set and fruit quality were determined similarly to the manner described in Expt. 4. Fruits and leaves for analysis of total soluble sugars and starch, were collected at $0,5,9$, and $13 \mathrm{~d}$ after BA application, and were determined as described previously.

Fruit thinNing, abSCISSION, AND NONSTRUCTURAL CARBOHYDRATE STATUS IN 1997 (EXPT. 6). Effects of BA on the time course of fruit abscission, and the status of nonstructural carbohydrates in persisting and abscising fruit were evaluated in 1997. Eight mature "More-Spur McIntosh'/M.7 apple trees, were selected and grouped based upon vigor and blossom cluster density into four blocks of two trees each. A randomized complete block design was used. Two limbs on each tree, 12 to $15 \mathrm{~cm}$ in diameter, were tagged and all blossom clusters were counted before bloom. One tree in each block was sprayed with BA at $100 \mathrm{mg} \cdot \mathrm{L}^{-1}$ on 6 June 1997 , at the $10-\mathrm{mm}$

Table 1. Effects of BA application to leaves or fruit on the translocation of ${ }^{14} \mathrm{C}$-sorbitol from leaves to the fruit of 'More-Spur McIntosh' apples (Expts. 1 and 2). ${ }^{\mathrm{Z}}$

\begin{tabular}{|c|c|c|c|}
\hline \multirow[b]{3}{*}{ Treatments $^{y}$} & \multicolumn{3}{|c|}{${ }^{14} \mathrm{C}\left(\mathrm{Bq} \cdot \mathrm{g}^{-1} \mathrm{DW}\right)$} \\
\hline & \multirow{2}{*}{$\frac{1995}{24 \mathrm{~h}^{\mathrm{x}}}$} & \multicolumn{2}{|c|}{1996} \\
\hline & & $24 \mathrm{~h}$ & $48 \mathrm{~h}$ \\
\hline Control & $800 b^{w}$ & $3000 \mathrm{~b}$ & $4233 \mathrm{~b}$ \\
\hline BA to the fruit & $1267 \mathrm{a}$ & $3833 \mathrm{a}$ & $5000 \mathrm{a}$ \\
\hline BA to the leaves & $1000 \mathrm{ab}$ & $2683 \mathrm{~b}$ & $4467 \mathrm{~b}$ \\
\hline
\end{tabular}

${ }^{\mathrm{z}}$ Mean of 10 observations.

${ }^{\mathrm{B}} \mathrm{BA}$ at $100 \mathrm{mg} \cdot \mathrm{L}^{-1}$ was applied at $10 \mathrm{~mm}$ stage of fruit development.

xTranslocation period.

wMean separation within columns by Duncan's multiple range test, $P<$ 0.05 . 


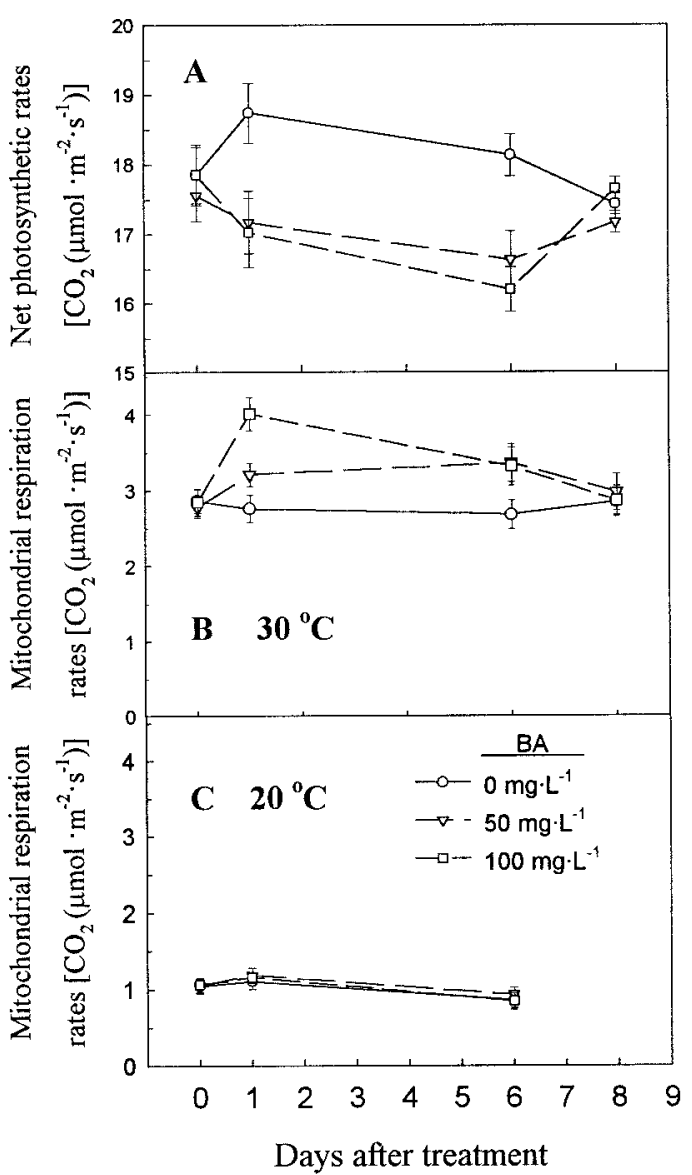

Fig. 1. Effects of BA on (A) net photosynthetic rates, and mitochondrial respiration rates of 'More-Spur McIntosh' apple leaves at $\approx 30^{\circ} \mathrm{C}(\mathbf{B})$ and $20^{\circ} \mathrm{C}(\mathbf{C})$ (Expt. 3, 1996). Legend in $\mathbf{C}$ applies to all figures. Data are means \pm SE $(n=8)$.

stage of fruit development. One tree in each block was not treated and served as a control. Fruit on tagged limbs were counted just before BA application and then fruit remaining on tagged limbs were counted every 3 or $4 \mathrm{~d}$.

Two types of fruit were collected $12 \mathrm{~d}$ after BA application: persisting fruit which continued to develop to commercial harvest, and abscising fruit of the same age as persisting fruit. Abscising fruit were starting to show signs of abscission, as evidenced by a yellowing pedicel. A third type of fruit, abscising fruit with the same diameter as that of the persisting fruit sampled at $12 \mathrm{~d}$ after BA application, were sampled $24 \mathrm{~d}$ after BA application. These fruit were also identified by a yellowing pedicel. Fifteen fruits of each type were collected from each tree, and weighed, and their equatorial diameter was measured. Total soluble sugars, starch, and total nonstructural carbohydrates were assayed as described in Expt. 4.

Statistical analyses. Statistical analyses included analysis of variance, Duncan's multiple range test, $t$ test, and orthogonal polynomial comparison. When interactions of main effects were significant, sums of squares were partitioned into the sums of squares of one main effect nested within each level of the other main effect involved in the interaction. Statistical Analysis Systems Software for PC (SAS Inst., Cary, N.C.) was used to analyze these data.

\section{Results}

${ }^{14}$ C-ASSimilate Movement. Compared with nontreated spurs, more ${ }^{14} \mathrm{C}$-sorbitol was translocated from the leaves to the fruit when BA was applied directly to the fruit in a spur (Table 1). However, there was no difference in ${ }^{14} \mathrm{C}$-sorbitol movement from leaves to fruit between nontreated spurs and those on which only the leaves were treated. Overall, more ${ }^{14} \mathrm{C}$-sorbitol moved from the leaves to fruit in $48 \mathrm{~h}$ than in $24 \mathrm{~h}$, regardless of treatments.

NET PHOTOSYNTHESIS AND RESPIRATION. BA at 50 or $100 \mathrm{mg} \cdot \mathrm{L}^{-1}$ equally decreased $P_{n}$ of apple leaves at 1 and $6 \mathrm{~d}$ after treatment, but had no effect at $8 \mathrm{~d}$ after treatment (Fig. $1 \mathrm{~A}$ ). At $30^{\circ} \mathrm{C}$, BA treatments increased mitochondrial respiration rates of apple leaves 1 and $6 \mathrm{~d}$ after treatment (Fig. 1B). However, mitochondrial respiration rates of apple leaves treated with BA recovered to the control rate by $8 \mathrm{~d}$ after treatment. There was no significant difference in mitochondrial respiration rates of apple leaves between BA treatments. At 20 ${ }^{\circ} \mathrm{C}$, BA had no significant influence on mitochondrial respiration rates of apple leaves (Fig. 1C). Mitochondrial respiration rates of apple leaves were considerably higher at $30^{\circ} \mathrm{C}$ than at $20^{\circ} \mathrm{C}$ regardless of BA treatment.

FrUIT THINNING, ABSCISSION, AND NONSTRUCTURAL CARBOHYDRATE STATUS. BA effectively thinned 'More-Spur McIntosh' apples in the three experiments reported herein (Table 2). The response to BA concentration was primarily linear. Fruit weight at harvest increased with increasing concentrations of BA (Table 2).

There were two distinguishable fruit abscission peaks during 'June drop' in 'More-Spur McIntosh' apples regardless of BA treatment (Fig. 2). The large and small abscission peaks occurred 14 and $24 \mathrm{~d}$ after treatment, respectively. About $54 \%$ of then existing fruit on BA treated trees abscised from 10 to $14 \mathrm{~d}$ after BA treatment, compared with $25 \%$ fruit abscission on control trees.

Table 2. Effects of BA on fruit set and mean fruit weight at harvest of 'More-Spur McIntosh' apples in 3 years (Expts. 4, 5, and 6). ${ }^{\mathrm{z}}$

\begin{tabular}{|c|c|c|c|c|c|c|}
\hline \multirow[b]{2}{*}{$\begin{array}{l}\mathrm{BA}^{\mathrm{y}} \\
\left(\mathrm{mg} \cdot \mathrm{L}^{-1}\right)\end{array}$} & \multicolumn{2}{|c|}{1995} & \multicolumn{2}{|c|}{1996} & \multicolumn{2}{|c|}{1997} \\
\hline & $\begin{array}{c}\text { Fruit/ } \\
\mathrm{cm}^{2} \\
\mathrm{LCSA}^{\mathrm{x}}\end{array}$ & $\begin{array}{c}\text { Fruit } \\
\text { wt } \\
(\mathrm{g})\end{array}$ & $\begin{array}{c}\begin{array}{c}\text { Fruit/ } \\
\mathrm{cm}^{2} \\
\text { LCSA }\end{array} \\
\end{array}$ & $\begin{array}{c}\text { Fruit } \\
\text { wt } \\
(\mathrm{g})\end{array}$ & $\begin{array}{c}\begin{array}{c}\text { Fruit/ } \\
\mathrm{cm}^{2} \\
\text { LCSA }\end{array}\end{array}$ & $\begin{array}{c}\text { Fruit } \\
\text { wt } \\
(\mathrm{g})\end{array}$ \\
\hline 0 & 13.2 & 125 & 6.3 & 156 & 11.3 & 111 \\
\hline 50 & 9.8 & 152 & 3.9 & 163 & --- & --- \\
\hline 100 & 7.8 & 161 & 3.0 & 181 & 5.5 & 171 \\
\hline \multicolumn{7}{|l|}{ Significance } \\
\hline Linear & $* *$ & $* * *$ & $* *$ & $* * *$ & $* * \mathrm{w}$ & $* * * \mathrm{w}$ \\
\hline Quadratic & NS & $* *$ & NS & NS & & \\
\hline
\end{tabular}

${ }^{\mathrm{z}}$ Mean of eight observations.

yBA was applied at $10 \mathrm{~mm}$ stage of fruit development.

${ }^{x}$ LCSA $=$ limb cross-sectional area.

${ }^{\text {w}}$ Mean separation within columns by $t$ test.

Ns,**,**** Nonsignificant or significant at $P<0.01$ or 0.001 , respectively. 
Generally, the concentration of total nonstructural carbohydrates, total soluble sugars, and starch in the apple leaves decreased dramatically with time regardless of BA treatment in the two (Figs. 3 and 4) experiments reported herein (Figs. 3 and 4). In 1995, BA reduced the concentration of total nonstructural carbohydrates, total soluble sugars, and starch in apple leaves 5 and $8 \mathrm{~d}$ after treatment, but this difference disappeared $12 \mathrm{~d}$ after treatment (Fig. 3). In 1996, total nonstructural carbohydrates and total soluble sugars were considerably lower in the leaves of BA-treated trees than those of the control trees at 5 and $9 \mathrm{~d}$ after treatment (Fig. 4). BA had no significant influence on starch levels in the leaves. The trend of carbohydrate content in the leaves and its response to BA application were similar to that of the concentration of carbohydrates in the leaves (unpublished data).

BA did not significantly affect concentrations of total nonstructural carbohydrates, total soluble sugars, and starch in the fruit in either year, except in 1996, where BA at $100 \mathrm{mg} \cdot \mathrm{L}^{-1}$ reduced starch concentration in fruit $9 \mathrm{~d}$ after treatment (Figs. 5 and 6).

On 18 June 1997, 12 d after BA application, average fruit size of abscising fruit was $32 \%$ smaller than that of persisting fruit, whereas the fruit size of the fruit abscising $12 \mathrm{~d}$ later (30 June) was similar to persisting fruit (18 June) (Table 3). Abscising fruit the same age had lower fresh weight (FW) and dry weight (DW) than persisting fruit. Persisting fruit had higher water content than abscising fruit either 12 or $24 \mathrm{~d}$ after BA application.

Concentrations of total soluble sugars and total nonstructural carbohydrates were greater in abscising fruit than in persisting fruit (Table 4). The concentration of starch was highest in abscising fruit the same size as persisting fruit, whereas starch concentration was similar in persisting fruit and abscising fruit at the same harvest date.

\section{Discussion}

Photosynthates required for young fruit to grow and develop are produced in the leaves, and must be translocated from the leaves to

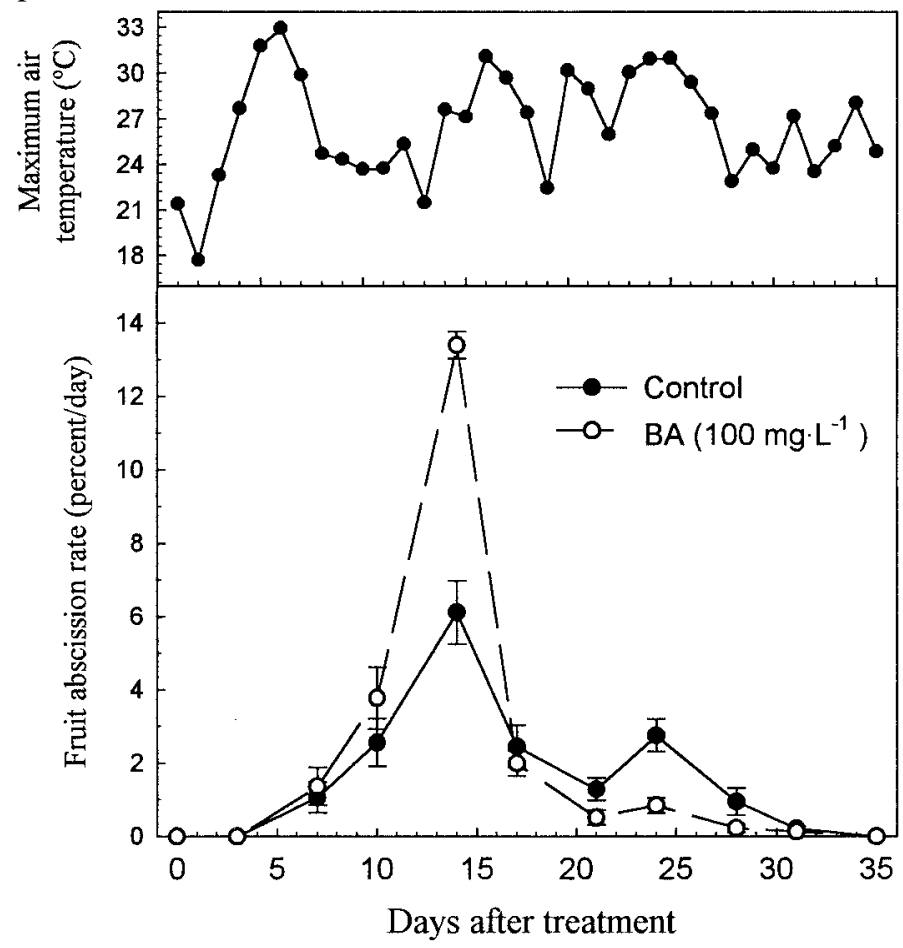

Fig. 2. Effects of BA on the patterns of fruit abscission of 'More-Spur McIntosh' apples during 'June drop' (Expt. 6, 1997). Data are means \pm SE $(n=8)$. the fruit. Schneider (1978) suggested that the mechanism of fruit thinning by NAA was interference with photosynthate transport from leaves to fruit since NAA decreased both the concentration and content of reducing sugars in the flesh of young fruit (Schneider and Lasheen, 1973) and reduced translocation of sugars from leaves to the developing apples (Schneider, 1975). In our investigation, BA enhanced rather than reduced translocation of ${ }^{14} \mathrm{C}$-sorbitol from spur leaves to fruit when applied directly to the 'More-Spur McIntosh' fruit, but not when applied directly to the leaves (Table 1). Similarly, BA promoted sugar movement from the foliage to the developing fruit in citrus (Mauk et al., 1986). Sorbitol and sucrose are the principal carbohydrates translocated in apples (Webb and Burley,

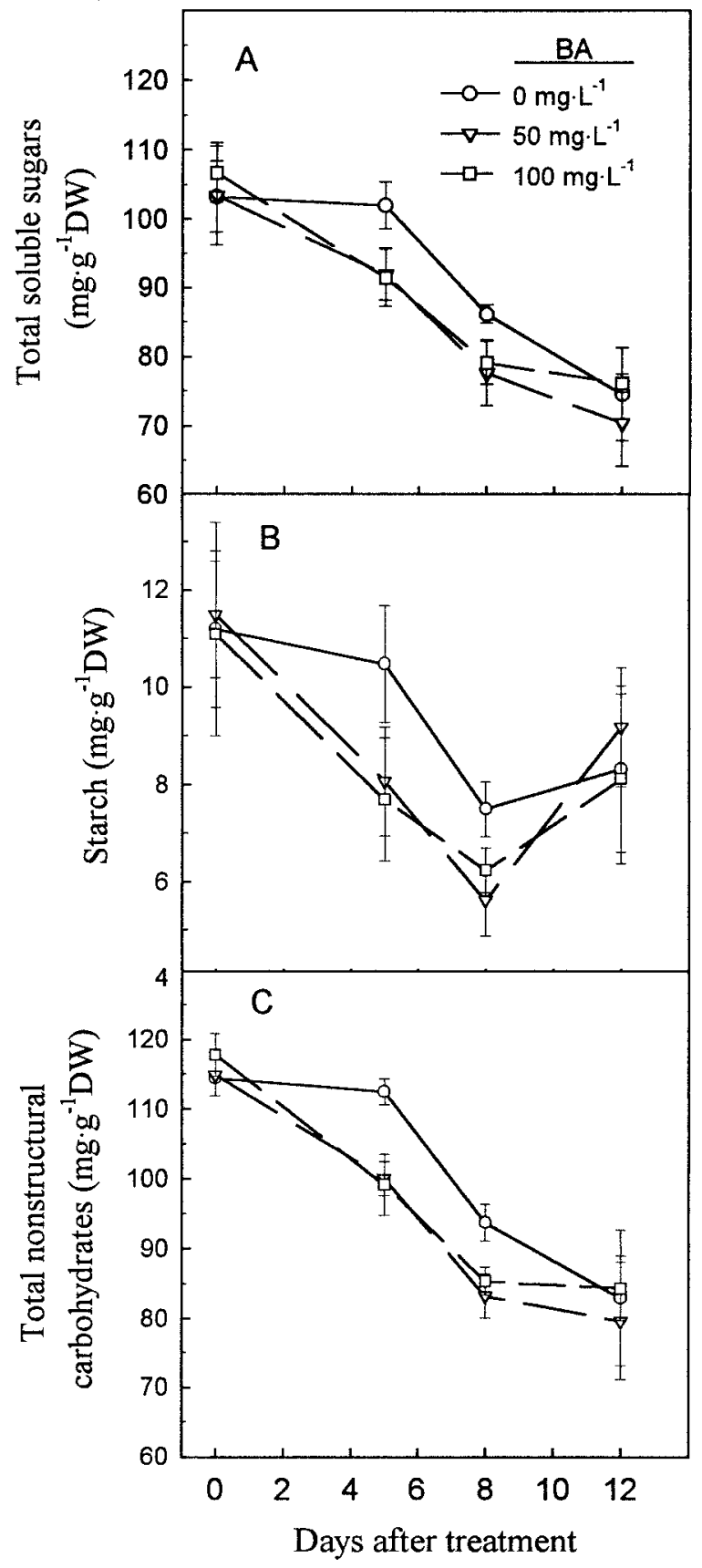

Fig. 3. Effects of BA on nonstructural carbohydrate levels of 'More-Spur McIntosh' apple leaves (Expt. 4, 1995). (A) Total soluble sugars, (B) starch, (C) total nonstructural carbohydrates. Legend in $\mathbf{A}$ applies to all figures. Data are means \pm SE $(n=5)$. 
1962). Since BA must come in contact with the leaves to thin (Greene et al., 1992), it is unlikely that BA thinned apples directly by restricting the translocation of photosynthates from leaves to fruit.

Foliar application of BA reduced $\mathrm{P}_{\mathrm{n}}$ of 'More-Spur McIntosh' apple leaves at $30 \pm 2{ }^{\circ} \mathrm{C}$ by $10 \%$ to $15 \%$ (Fig. 3A). This suppression persisted for $\approx 6 \mathrm{~d}$. Following petal fall, fruit growth, leaf area, and shoot growth increase rapidly. There is a high demand for energy produced by photosynthesis of leaves at these multiple centers of metabolic activity (Hansen, 1971; Quinlan and Preston, 1971). Shading or application of photosynthetic inhibitors during this critical time, which decreases photosynthesis and thus reduces the carbohydrates available to the fruit, has been suggested as a primary

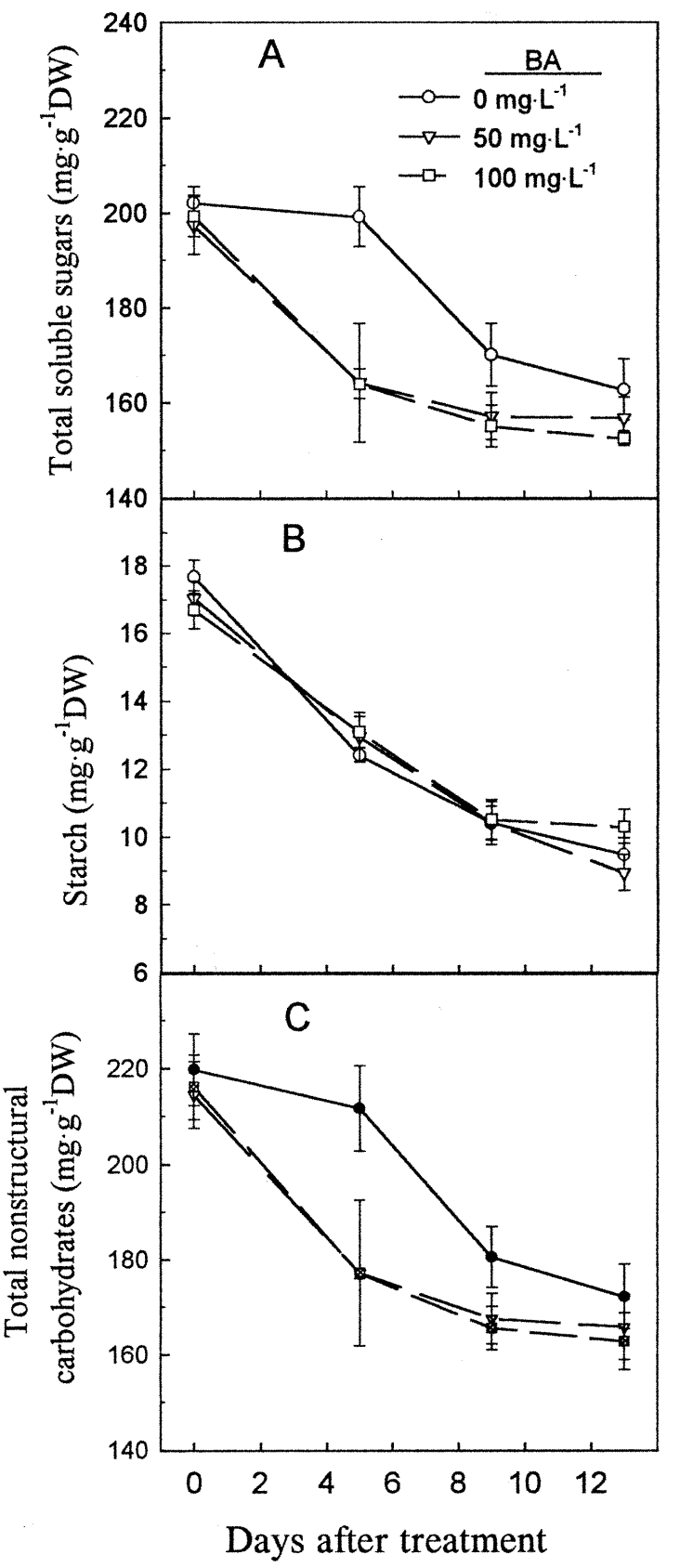

Fig. 4. Effects of BA on nonstructural carbohydrate levels of 'More-Spur McIntosh' apple leaves (Expt. 5, 1996). (A) Total soluble sugars, (B) starch, (C) total nonstructural carbohydrates. Legend in A applies to all figures. Data are means \pm SE $(n=5)$. factor responsible for increasing early fruit abscission of apple (Byers et al., 1985; 1990; 1991; Schneider, 1978), peach [Prunus persica (L.) Batsch] (Byers et al., 1985), sweet orange [Citrus sinensis ( L.) Osbeck] (Moss, 1976), and litchi (Litchi chinesis Sonn.) (Yuan and Huang, 1988). Even shading with cloth to reduce light interception of 'Delicious' apple trees by $25 \%$ for $2 \mathrm{~d}$ caused significant fruit abscission (Schneider, 1978). Carbon balance models indicate a potential limitation of carbon availability during the first 5 weeks after bloom, a critical period for fruit set and fruit cell division (Lakso and Corelli Grappadelli, 1992). Thus, it is reasonable to assume that a $10 \%$ to $15 \%$ reduction in $\mathrm{P}_{\mathrm{n}}$ of apple leaves following BA application, sustained for several days, may be an important factor contributing to the early fruit abscission.

$P_{n}$ is determined by three factors (Pasian and Lieth, 1989). First,

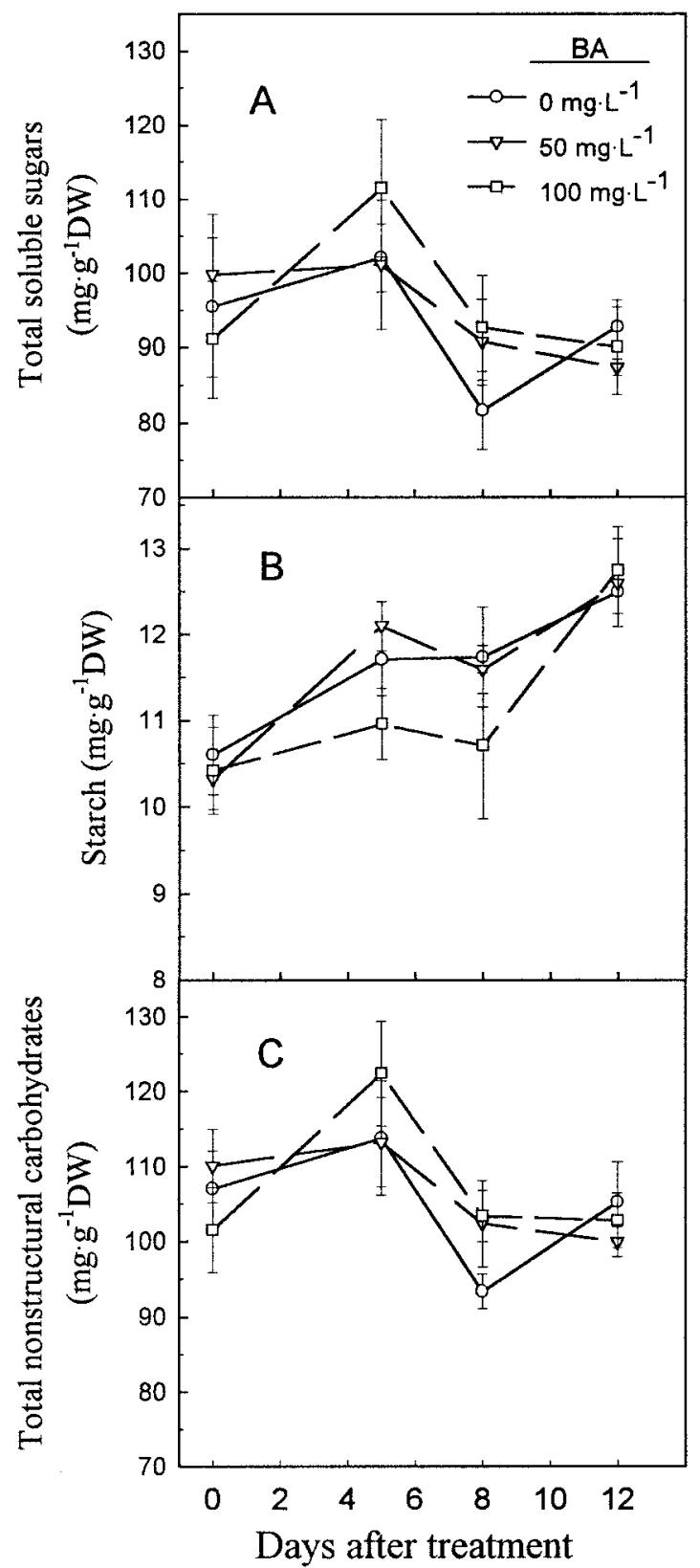

Fig. 5. Effects of BA on nonstructural carbohydrate levels of 'More-Spur McIntosh' apples (Expt. 4, 1995). (A) Total soluble sugars, (B) starch, (C) total nonstructural carbohydrates. Legend in $\mathbf{A}$ applies to all figures. Data are means \pm SE $(n=5)$. 


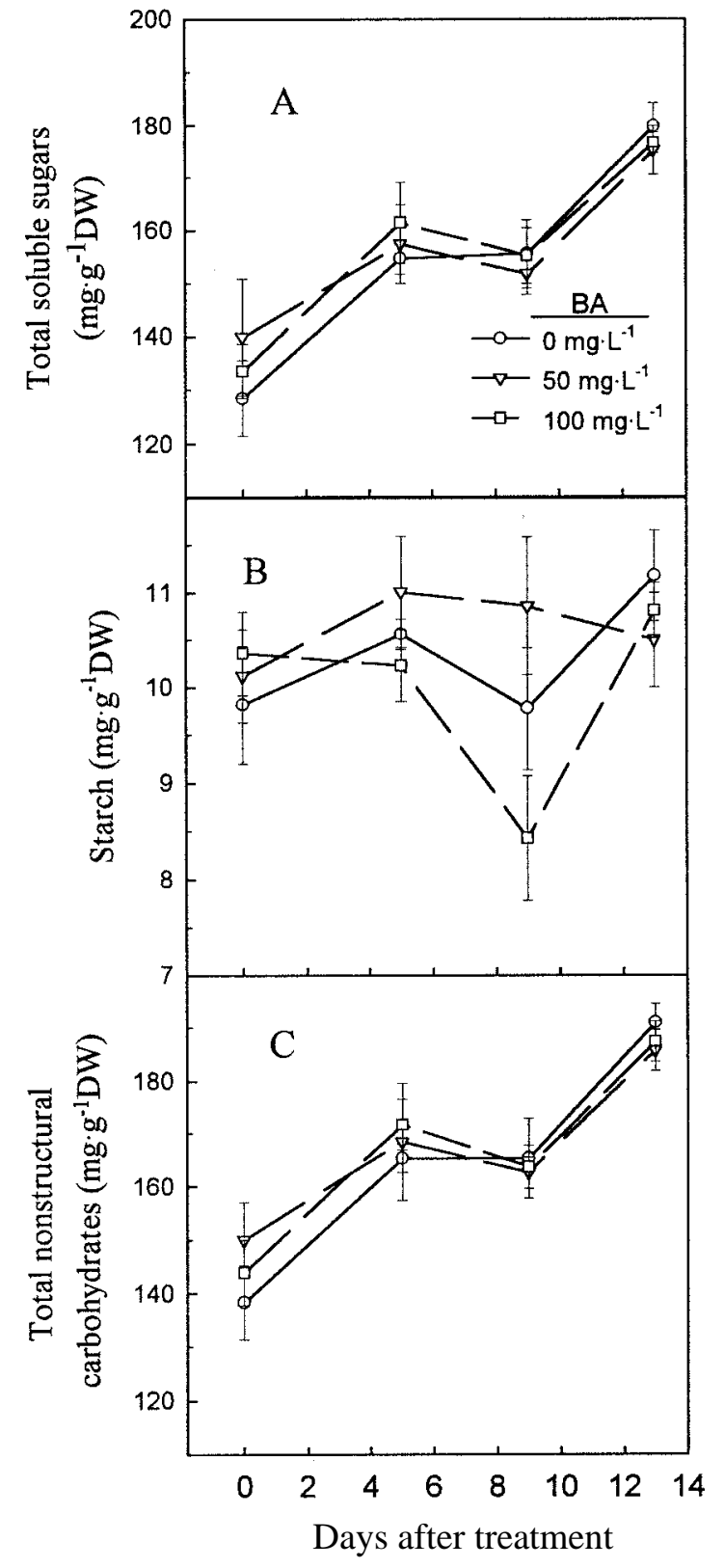

Fig. 6. Effects of BA on nonstructural carbohydrate levels of 'More-Spur McIntosh' apples (Expt. 5, 1996). (A) Total soluble sugars, (B) starch, (C) total nonstructural carbohydrates. Legend in $\mathbf{A}$ applies to all figures. Data are means \pm SE $(n=5)$.

gross leaf photosynthesis $\left(\mathrm{P}_{\mathrm{g}}\right)$, is the total amount of carbon fixed by the plant. The second and third, which consume some of the photosynthates, are photorespiration $\left(\mathrm{R}_{\mathrm{p}}\right)$ and mitochondrial respiration $\left(R_{m}\right)$ of the leaves. Stated differently $P_{n}=P_{g}-\left(R_{m}+R_{p}\right)$, or $P_{n}$ $+R_{m}=P_{g}-R_{p}$, and $P_{n}+R_{m}=P$, where $P=P_{g}-R_{p}$. In our investigation, there was no significant difference in the sum of $P_{n}$ and mitochondrial respiration among treatments and control (data not presented) which meant that $\mathrm{P}$ did not change in value. Therefore, the reduced $\mathrm{P}_{\mathrm{n}}$ following BA application resulted mainly from increased mitochondrial respiration caused by BA application. However, the response of leaf mitochondrial respiration to BA application was temperature dependent. Leaf respiration was increased when temperature following BA application was high $\left(\approx 30^{\circ} \mathrm{C}\right)$ (Fig. 1B), whereas there was no effect when temperature was lower $\left(20^{\circ} \mathrm{C}\right)$ (Fig. 1C). The temperature-dependence of mitochondrial respira- tion may explain the erratic thinning observed following BA application. Stopar et al. (1997) reported that BA at $50 \mathrm{mg} \cdot \mathrm{L}^{-1}$ reduced $\mathrm{P}_{\mathrm{n}}$ by $10 \%$ in 'Redchief Delicious' but this was not statistically different from the control. However, they did not report the temperature when $P_{n}$ was measured. Furthermore, the $P_{n}$ that they reported ranged from 12 to $15 \mu \mathrm{mol} \cdot \mathrm{m}^{-2} \cdot \mathrm{s}^{-1}$, which is relatively low compared with $\approx 20 \mu \mathrm{mol} \cdot \mathrm{m}^{-2} \cdot \mathrm{s}^{-1}$ reported by Schechter et al. (1994) and 18 to $19 \mu \mathrm{mol} \cdot \mathrm{m}^{-2} \cdot \mathrm{s}^{-1}$ in our investigation.

Generally, there is more than one peak in fruit abscission during 'June drop' (Abruzzese et al., 1995). In our investigation, there were two waves of fruit abscission during the 'June drop' period on 'More-Spur McIntosh' apples, regardless of BA application (Fig. 2). These peaks appear to be innate but the peak value may be affected by the weather. Application of BA significantly increased the first peak, which occurred between 10 and $14 \mathrm{~d}$ after BA treatment. At this time, approximately half of then existing fruit abscised from treated trees in $4 \mathrm{~d}$, whereas only $25 \%$ abscised from the control trees. Therefore, BA appears to accentuate naturally occurring waves of fruit abscission. It also indicated the importance of the time of BA application, since application made too far in advance or following a fruit abscission peak may result in insufficient thinning (Bound et al., 1991; Greene and Autio, 1989). Similarly, Byers et al. (1991) found that artificially shading for 2 to $3 \mathrm{~d}$ almost defruited trees when shaded 14, 21, or $28 \mathrm{~d}$ after full bloom, but it did not reduce fruit set when shaded 8,35 , or $42 \mathrm{~d}$ after full bloom.

Concentration of carbohydrates in 'More-Spur McIntosh' apple leaves decreased dramatically over the 12 or 13 d observation period (Figs. 3 and 4), suggesting that carbohydrates available to developing fruit and growing bourse shoots were potentially limiting during

Table 3. The effect of BA on fruit diameter, fruit fresh weight, fruit dry weight, and fruit water content of persisting and abscising 'More-Spur McIntosh' apples (Expt. 6, 1997). ${ }^{\mathrm{z}}$

\begin{tabular}{|c|c|c|c|}
\hline \multirow[b]{2}{*}{$\begin{array}{l}\text { BA } \\
\left(\mathrm{mg} \cdot \mathrm{L}^{-1}\right)^{\mathrm{y}}\end{array}$} & \multicolumn{3}{|c|}{ Fruit } \\
\hline & $\begin{array}{l}\text { Persisting } \\
{\text { (18 June })^{\mathrm{X}}}\end{array}$ & $\begin{array}{l}\text { Abscising } \\
\text { (18 June) } \\
\left(_{(\text {same age })^{\mathrm{x}}}\right.\end{array}$ & $\begin{array}{c}\text { Abscising } \\
\text { (30 June) } \\
\text { (same size) }^{\mathrm{w}}\end{array}$ \\
\hline & \multicolumn{3}{|c|}{ Fruit diam $(\mathrm{mm})$} \\
\hline 0 & 25.4 & 17.6 & 25.2 \\
\hline 100 & $25.8^{\mathrm{NS}}$ & $17.2^{\mathrm{NS}}$ & $25.6^{\mathrm{NS}}$ \\
\hline \multirow[t]{2}{*}{ Mean } & $25.6 \mathrm{a}^{\mathrm{v}}$ & $17.4 \mathrm{~b}$ & $25.4 \mathrm{a}$ \\
\hline & \multicolumn{3}{|c|}{ Fresh wt/fruit (g) } \\
\hline 0 & 8.2 & 2.8 & 7.4 \\
\hline 100 & $8.3^{\mathrm{NS}}$ & $2.9^{\mathrm{NS}}$ & $7.8^{\mathrm{NS}}$ \\
\hline \multirow[t]{2}{*}{ Mean } & $8.2 \mathrm{a}$ & $2.9 \mathrm{c}$ & $7.6 \mathrm{~b}$ \\
\hline & \multicolumn{3}{|c|}{ Dry wt/fruit (g) } \\
\hline 0 & 0.9 & 0.4 & 0.9 \\
\hline 100 & $0.9^{\mathrm{NS}}$ & $0.4^{\mathrm{NS}}$ & $1.0^{\mathrm{NS}}$ \\
\hline \multirow[t]{2}{*}{ Mean } & $0.9 \mathrm{~b}$ & $0.4 \mathrm{c}$ & $1.0 \mathrm{a}$ \\
\hline & \multicolumn{3}{|c|}{ Water/fruit (g) } \\
\hline 0 & 7.3 & 2.5 & 6.5 \\
\hline 100 & $7.4^{\mathrm{NS}}$ & $2.5^{\mathrm{NS}}$ & $6.8^{\mathrm{NS}}$ \\
\hline Mean & $7.3 \mathrm{a}$ & $2.5 \mathrm{c}$ & $6.7 \mathrm{~b}$ \\
\hline
\end{tabular}

${ }^{\mathrm{z}}$ Mean of four observations.

yBA was applied on 6 June 1997, at 10-mm stage of fruit development.

xTwelve days after BA application.

wTwenty-four days after BA application.

'Mean separation within rows by Duncan's multiple range test, $P<0.05$.

${ }^{\text {ss }}$ Difference in mean between BA at $0 \mathrm{mg} \cdot \mathrm{L}^{-1}$ and $100 \mathrm{mg} \cdot \mathrm{L}^{-1}$ was nonsignificant according to $t$ test, $P<0.05$. 
Table 4. Effects of BA on total soluble sugars, starch, and total nonstructural carbohydrates (TNC) of persisting and abscising 'More-Spur McIntosh' apples (Expt. 6, 1997) ${ }^{\mathrm{Z}}$

\begin{tabular}{|c|c|c|c|}
\hline \multirow[b]{2}{*}{$\begin{array}{l}\text { BA } \\
\left(\mathrm{mg} \cdot \mathrm{L}^{-1}\right)^{y}\end{array}$} & \multicolumn{3}{|c|}{ Fruit } \\
\hline & $\begin{array}{l}\text { Persisting } \\
(18 \text { June })^{\mathrm{x}}\end{array}$ & 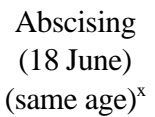 & $\begin{array}{c}\text { Abscising } \\
\text { (30 June) } \\
\text { (same size) }\end{array}$ \\
\hline & \multicolumn{3}{|c|}{ Total soluble sugars $\left(\mathrm{mg} \cdot \mathrm{g}^{-1} \mathrm{dry} \mathrm{wt}\right)$} \\
\hline 0 & 198.4 & 228.2 & 312.7 \\
\hline 100 & $194.6^{\mathrm{NS}}$ & $238.3^{\mathrm{NS}}$ & $320.0^{\mathrm{NS}}$ \\
\hline \multirow[t]{2}{*}{ Mean } & $196.2 \mathrm{c}^{\mathrm{v}}$ & $233.2 \mathrm{~b}$ & $316.3 \mathrm{a}$ \\
\hline & \multicolumn{3}{|c|}{ Starch (mg.g $\mathrm{g}^{-1}$ dry wt) } \\
\hline 0 & 18.8 & 15.65 & 27.5 \\
\hline 100 & $15.0^{\mathrm{NS}}$ & $13.2^{\mathrm{NS}}$ & $26.3^{\mathrm{NS}}$ \\
\hline \multirow[t]{2}{*}{ Mean } & $16.9 \mathrm{~b}$ & $14.4 \mathrm{~b}$ & $26.9 \mathrm{a}$ \\
\hline & \multicolumn{3}{|c|}{$\mathrm{TNC}\left(\mathrm{mg} \cdot \mathrm{g}^{-1}\right.$ dry wt) } \\
\hline 0 & 214.9 & 243.9 & 340.2 \\
\hline 100 & $210.1^{\mathrm{NS}}$ & $251.5^{\mathrm{NS}}$ & $346.3^{\mathrm{NS}}$ \\
\hline Mean & $212.2 \mathrm{c}$ & $247.7 \mathrm{~b}$ & $343.3 \mathrm{a}$ \\
\hline
\end{tabular}

${ }^{\mathrm{z} \text { Mean of four observations. }}$

yBA was applied on 6 June 1997, at 10-mm stage of fruit development.

${ }^{\mathrm{x}}$ Twelve days after BA application.

wTwenty-four days after BA application.

'Mean separation within rows by Duncan's multiple range test, $P<0.05$.

${ }^{\text {Ns }}$ Difference in mean between BA at $0 \mathrm{mg} \cdot \mathrm{L}^{-1}$ and $100 \mathrm{mg} \cdot \mathrm{L}^{-1}$ was nonsignificant according to $t$ test, $P<0.05$.

the time of early fruit development. The carbohydrate concentration in apple leaves were lowered further by BA application, indicating that the available carbohydrate supply for developing fruit and growing bourse shoot was aggravated further by reduced $P_{n}$ resulting from BA application, thus causing further carbon stress and additional fruit abscission. Similarly, reduced soluble carbohydrate level in the leaves and a limited carbohydrate supply caused by increased respiration at high temperature or low light was suggested as a primary factor responsible for serious premature abscission of fruit in apple (Kondo and Takahashi, 1987), cyathia in poinsettia (Euphorbia pulcherrima Willd.) (Miller and Heins, 1986), and young bolls of cotton (Gossypium hirsutum L.) (Guinn, 1976).

Our results show that abscising fruit, regardless of BA treatment, contained higher carbohydrate concentrations than persisting fruit (Table 4). Similar results were also observed in apples (Abruzzese et al., 1995) and navel oranges (Ruiz and Guardiola, 1994). Abscised or abscising apples had higher calcium content, and lower DW, nitrogen, potassium, amino acids, and proteins than persisting fruit (Abruzzese et al., 1995; Howlett, 1923). The reason for high soluble sugars in abscising or abscised fruit was attributed to a reduction in their use (Abruzzese et al., 1995), since fruit growth reduced or slowed down 1 to 2 weeks before abscission (Abruzzese et al., 1995; Ruiz and Guardiola, 1994), and fruit also had greatly lower respiration rates before abscission (Stopar, 1998). Byers et al. (1991) reported that fruit destined to abscise stopped growth from 1 to $6 \mathrm{~d}$ after a 3-d period of shading. Using metabolic heat rates of plant tissues as the indicator of metabolic activities of the tissues, Nzima et al. (1998) also found that shading of pistachio (Pistacia vera $\mathrm{L}$.) trees reduced photosynthesis and resulted in reduced metabolic activities of inflorescence buds, thereby promoting inflorescence bud abscission. Therefore, reduced fruit respiration or metabolic activities results in limited energy production which in turn reduces the synthesis of amino acids and proteins, and lowers amino acid and protein concentrations in abscising or abscised fruit.
At the same time, reduced respiration causes accumulation of soluble sugars. In our investigation, there was no significant difference in carbohydrate concentrations of fruit of BA-treated trees and nontreated trees (Figs. 5 and 6). This may be attributed to the sample containing some abscising fruit which usually have considerably higher carbohydrates, since $\approx 83 \%$ of then existing fruit of BAtreated trees abscised during 'June drop' (Fig. 2), and abscising fruit were not distinguished visually from persisting fruit until shortly before abscission.

In conclusion, it seems that BA thinned apples not directly by affecting the movement of carbohydrates from leaves to fruit, but by increasing mitochondrial respiration and decreasing net photosynthesis. Decreased $\mathrm{P}_{\mathrm{n}}$ led to limited carbohydrate supply, thereby accentuating fruit abscission. This suggestion is also supported by the fact that BA thinned apples only when one leaf per fruit was on the girdled small fruiting spur, but not when leaf number was greater than two (Yuan and Greene, 2000).

\section{Literature Cited}

Abruzzese, A., H. Mignani, and S.M. Cocucci. 1995. Nutritional status in apples and June drop. J. Amer. Soc. Hort. Sci. 120:71-74.

Belding, R.D. and E. Young. 1987. Shoot and root temperature effects on carbohydrate levels during budbreak in young apple trees. J. Amer. Soc. Hort. Sci. 112:596-599.

Bound, S.A., K.M. Jones, T.B. Koen, and M.J. Oakford. 1991. The thinning effect of benzyladenine on red 'Fuji' apple trees. J. Hort. Sci. 66:789-794.

Byers, R.E., J.A. Barden, and D.H. Carbaugh. 1990. Thinning of spur "Delicious' apples by shade, terbacil, carbaryl, and ethephon. J. Amer. Soc. Hort. Sci. 115:9-13.

Byers, R.E., D.H. Carbaugh, C.N. Presley, and T.K. Wolf. 1991. The influence of low light on apple fruit abscission. J. Hort. Sci. 66:7-17.

Byers, R.E., C.G. Lyons, Jr., K.S. Yoder, J.A. Barden, and R.W. Young. 1985. Peach and apple thinning by shading and photosynthetic inhibition. J. Hort. Sci. 60:465-472.

Childers, N. F, J.R. Morris, and G.S. Sibbett. 1995. Modern fruit science. 10th ed. Hort. Publ. Gainesville, Fla.

Dekker, R.F.H. and G.N. Richards. 1971. Determination of starch in plant material. J. Sci. Food Agr. 22:441-444.

Elfving, D.C. and R.A. Cline. 1993. Benzyladenine and other chemicals for thinning 'Empire' apple trees. J. Amer. Soc. Hort. Sci. 118:593598.

Flood, A.E. and C.A. Priestley. 1973. Two improved methods for determination of soluble carbohydrates. J. Sci. Food Agr. 24:945-955.

Greene, D.W. and W.R. Autio. 1989. Evaluation of benzyladenine as a chemical thinner on 'McIntosh' apples. J. Amer. Soc. Hort. Sci. 114:68-73.

Greene, D.W. and W.R. Autio. 1990. Vegetative responses of apple trees following benzyladenine and growth regulator sprays. J. Amer. Soc. Hort. Sci. 115:400-404.

Greene, D.W., W.R. Autio, J.A. Erf, and Z.Y. Mao. 1992. Mode of action of benzyladenine when used as a chemical thinner on apples. J. Amer. Soc. Hort. Sci. 117:775-779.

Greene, D.W., W.R. Autio, and P. Miller. 1990. Thinning activity of benzyladenine on several apple cultivars. J. Amer. Soc. Hort. Sci. 115:394-400.

Guinn, G. 1976. Nutritional stress and ethylene evolution by young cotton bolls. Crop Sci. 16:89-91.

Hansen, P. 1971. ${ }^{14} \mathrm{C}$-studies on apple trees. VII. The early season growth in leaves, flowers and shoots as dependent upon current photosynthates and existing reserves. Physiol. Plant. 25:469-473.

Howlett, F.S. 1923. Nitrogen and carbohydrate composition of the developing flowers and young fruits of the apple. Proc. Amer. Soc. Hort. Sci. 20:31-37.

Kondo, S. and Takahashi. Y. 1987. Effects of high temperature in the night time and shading in the day time on the early drop of apple fruit 
'Starking Delicious'. J. Jpn. Soc. Hort. Sci. 56:142-150.

Lakso, A.N. and L. Corelli Grappadelli. 1992. Implications of pruning and training practices to carbon partitioning and fruit development in apple. Acta Hort. 322:231-239.

Mauk, C.S., M.G. Bausher, and G. Yelenosky. 1986. Influence of growth regulator treatments on dry matter production, fruit abscission, and ${ }^{14} \mathrm{C}$ assimilate partitioning in citrus. J. Plant Growth Regulat. 5:111-120.

Mclaughlin, J.M. and D.W. Greene. 1984. Effects of BA, GA4+7, and daminozide on fruit set, fruit quality, vegetative growth, flower initiation, and flower quality of 'Golden Delicious' apples. J. Amer. Soc. Hort. Sci. 109:34-39.

Miller, S.H. and R.D. Heins. 1986. Factors influencing premature cyathia abscission in poinsettia 'Annette Hegg Dark Red'. J. Amer. Soc. Hort. Sci. 111:114-121.

Moss, G.I. 1976. Thinning 'Washington' navel and 'Late Valencia' sweet orange fruits with photosynthetic inhibitors. HortScience 11:4850.

Nzima, M.D.S., G.C. Martin, and R.W. Breidenbach. 1998. Fruiting and shading effects on metabolic heat rates of inflorescence buds, currentyear, and one-year-old shoots of 'Kerman' pistachio trees. J. Amer. Soc. Hort. Sci. 123:961-966.

Pasian, C.C. and J.H. Lieth. 1989. Analysis of the response of net photosynthesis of rose leaves of varying ages to photosynthetically active radiation and temperature. J. Amer. Soc. Hort. Sci. 114:581586.

Polomski, R.F., J.A. Barden, R.E. Byers, and D.D. Wolf. 1988. Apple fruit nonstructural carbohydrates and abscission as influenced by shade and terbacil. J. Amer. Soc. Hort. Sci. 113:506-511.

Quinlan, J.D. and A.P.Preston. 1971. The influence of shoot competition on fruit retention and cropping of apple trees. J. Hort. Sci. 46:525-534.
Ruiz, R. and J.L. Guardiola. 1994. Carbohydrate and mineral nutrition of orange fruitlets in relation to growth and abscission. Physiol. Plant. 90:27-36.

Schechter, I., J.T.A. Proctor, and D.C. Elfving. 1994. Carbon exchange rate and accumulation in limbs of fruiting and nonfruiting apple trees. J. Amer. Soc. Hort. Sci. 119:150-156.

Schneider, G.W. 1975. ${ }^{14} \mathrm{C}$-sucrose translocation in apple. J. Amer. Soc Hort. Sci. 100:22-24.

Schneider, G. W. 1978. Abscission mechanism studies with apple fruitlets. J. Amer. Soc. Hort. Sci. 103:455-458.

Schneider, G.W. and A.M. Lasheen. 1973. NAA and Sevin on composition, development, and abscission of apple fruit. HortScience 8:103104.

Stopar, M., B.L. Black, and M.J. Bukovac. 1997. The effect of NAA and $\mathrm{BA}$ on $\mathrm{CO}_{2}$ assimilation by shoot leaves of spur-type 'Delicious' and 'Empire' apple trees. J. Amer. Soc. Hort. Sci. 122:837-840.

Stopar, M. 1998. Apple fruit thinning and photosynthate supply. J. Hort. Sci. Biotech. 73:461-466.

Webb, K.L. and J.W.A. Burley. 1962. Sorbitol translocation in apple. Science 137:766.

Wismer, P.T., J.T.A. Proctor, and D.C. Elfving. 1995. Benzyladenine affects cell division and cell size during apple fruit thinning. J. Amer. Soc. Hort. Sci. 120:802-807.

Yuan, R. and D.W. Greene. 2000. Benzyladenine as a chemical thinner for 'McIntosh' apples. II. Effects of benzyladenine, bourse shoot tip removal, and leaf number on fruit retention. J. Amer. Soc. Hort. Sci. 125(2):177-182.

Yuan, R. and H. Huang. 1988. Litchi fruit abscission: Its patterns, effect of shading and relation to endogenous abscisic acid. Scientia Hort. 36:281-292. 